\title{
KONTRIBUSI BERSYUKUR DAN MEMAAFKAN DALAM MENGEMBANGKAN KESEHATAN MENTAL DI TEMPAT KERJA
}

\author{
RAHMAT AZIZ ${ }^{*}$, ESA NUR WAHYUNI ${ }^{2}$ \& WILDANA WARGADINATA ${ }^{3}$ \\ 1Fakultas Psikologi, Universitas Islam Negeri Maulana Malik Ibrahim Malang \\ ${ }^{2}$ Fakultas Tarbiyah dan Ilmu Keguruan, Universitas Islam Negeri Maulana Malik Ibrahim Malang \\ ${ }^{3}$ Fakultas Humaniora, Universitas Islam Negeri Maulana Malik Ibrahim Malang
}

\begin{abstract}
ABSTRAK
Penelitian ini bertujuan untuk menguji besarnya kontribusi pemaafan dan syukur terhadap kesehatan mental di tempat kerja. Partisipan penelitian diambil dari karyawan dan dosen Universitas Islam Negeri Maulana Malik Ibrahim Malang sebanyak 167 orang melalui teknik pengambilan sampel proposional. Instrumen yang digunakan yaitu Skala pemaafan, skala syukur, dan Inventori Kesehatan Mental (MHI) ( $\alpha=.888$ ) yang telah dimodifikasi oleh penulis. Hasil analisis menunjukkan bahwa nilai $\mathrm{R}=.462 \mathrm{p}<.05$ dengan koefisien determinan sebesar .213 . Hal ini berarti pemaafan dan syukur mampu menjadi prediktor bagi tinggi rendahnya kesehatan mental sebesar 21.3 persen.
\end{abstract}

Kata kunci: pemaafan, syukur, kesehatan mental

\begin{abstract}
This research aimed to investigate the contribution of forgiveness and gratitude to mental health in work setting. Research participants were 167 lecturer and faculty staff of Islamic State University of Maulana Malik Ibrahim Malang. The sample were chosen using proportional sampling technique. Research instruments were forgiveness scale, gratitude scale and modified Mental Health Inventory (MHI) ( $\alpha=.888)$. Our research showed that $\mathrm{R}=.465(\mathrm{p}<.05)$ and determinant coefficient was .204. It implies that forgiveness and gratitude are good predictor for mental health and contributed around 20.4 percent.
\end{abstract}

Key words: forgiveness, gratitude, mental health

INSAN Jurnal Psikologi dan Kesehatan Mental, 2017, Vol. 2(1), 33-43, doi: 10.20473/jpkm.v2i12017.33-43 Dikirimkan: 28 Desember 2017 Diterima: 31 Mei 2017 Diterbitkan: 26 Juni 2017

Editor: Rizqy Amelia Zein

*Alamat korespondensi: Jalan Gajayana No. 50 Dinoyo, Kecamatan Lowokmaru, Kota Malang, Jawa Timur 65144 Surel: azira@uin-malang.ac.id

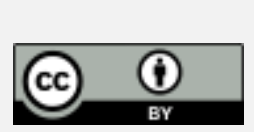

Naskah ini merupakan naskah dengan akses terbuka dibawah ketentuan the Creative Common Attribution License (http://creativecommons.org/licenses/by/4.0), sehingga penggunaan, distribusi, reproduksi dalam media apapun atas artikel ini tidak dibatasi, selama sumber aslinya disitir dengan baik.

\section{PENDAH U L U A N}

Kajian tentang produktivitas kerja sangat terkait oleh berbagai macam faktor. Salah satu faktor penting yang secara langsung maupun tidak langsung mempengaruhi produktivitas kerja adalah 
kesehatan mental. Hasil penelitian yang dilakukan oleh Koopman, dkk. (2002) menemukan bahwa produktivitas kerja dipengaruhi oleh kesehatan mental para pekerja. Dalam penelitiannya tersebut, Koopman, dkk. (2002) menemukan adanya hubungan yang sangat erat antara kedua variabel tersebut. Hal ini menunjukkan bahwa kesehatan mental mempunyai peran yang sangat penting dan strategis dalam menciptakan budaya organisasi yang efektif dan efisien.

Ada beberapa alasan mengapa kesehatan mental menjadi isu penting dalam dunia kerja. Danna dan Griffin (1999) menyatakan alasan pentingnya kesehatan mental di tempat kerja, yaitu; pertama, pengalaman individu baik fisik, emosional, mental, atau sosial akan mempengaruhi bagaimana individu di tempat kerja. Kedua, kesehatan mental pekerja menjadi bagian penting karena akan menumbuhkan kesadaran terhadap faktor-faktor lain yang menimbulkan resiko bagi pekerja. Misalkan, karakteristik tempat kerja yang mendukung keamanan dan kesejahteraan bagi pekerja, potensi ancaman kekerasan atau agresi di tempat kerja (kekerasan seksual dan bentuk-bentuk perilaku disfungsional lainnya), bahkan hubungan antara pimpinan dan bawahan yang berimplikasi pada kesehatan mental. Ketiga, kesehatan mental menjadi bagian penting karena kesehatan yang rendah akan mempengaruhi kinerja.

Memperkuat pernyataan di atas, hasil survei terhadap usia kerja di beberapa negara maju seperti di Australia dan Amerika menunjukkan saat ini diperkirakan satu dari enam usia kerja mengalami kondisi mental yang bermasalah (Harvey, 2014). Kondisi mental yang bermasalah ditenggarai telah menjadi penyebab tingginya angka ketidakhadiran (absence) dan ketidakmampuan (incapability) kerja yang menjadi penyebab rendahnya performan dan produktivitas di tempat kerja.

Banyak penelitian-penelitian yang mengangkat fenomena kesehatan mental dari berbagai perspektif, baik perspektif fisik, sosial, emosional, maupun mental. Penelitian yang dilakukan oleh Danna dan Griffin (1999) mengkaji literatur tentang kesehatan dan kesejahteraan di tempat kerja. Peneliti Cooper dan Cartwright (1994) mengkaji kesehatan mental dalam konteks organisasi yang sehat. Peneliti Marchand, dkk. (2015) meneliti faktor-faktor yang mempengaruhi kesehatan mental di tempat kerja. Peneliti Rees, Breen, Cusack dan Hegney (2015) mengkaji aspek resiliensi sebagai reseliensi dalam hubungannya dengan kesehatan mental.

Beberapa ahli berpendapat bahwa salah satu faktor yang mempengaruhi kesehatan mental di tempat kerja adalah hubungan interpersonal atau pola komunikasi antar individu (interpersonal relationship) yang ada di tempat kerja (Harvey, 2014; Danna \& Grifin 1999). Menurut Madsen, Gygi, Hammond dan Plowman (2009) hubungan interpersonal dan komunikasi yang effektif di tempat kerja akan berpengaruh terhadap kesehatan mental individu-individunya. Sebaliknya, hubungan interpersonal dan komunikasi yang tidak efektif akan menyebakan problem mental atau tekanan psikologis seperti kecemasan, depresi, dan stres di tempat kerja.

Sebagai sebuah sistem organisasi, komunikasi antar individu di tempat kerja sangat dinamis, sehingga tidak menutup kemungkinan menimbulkan konflik-konflik antar individu yang menyebabkan disharmonisasi komunikasi dan menyebabkan tekanan-tekanan psikologis. Beberapa isu-isu seperti adanya perbedaan pendapat diantara individu, adanya persaingan antar departemen, rumor-rumor yang menimbulkan perasaan benci, penilaian secara akurat maupun tidak akurat terhadap performan kerja, isu legalitas dan etika, serta kebijakan-kebijakan yang kurang mendukung telah menimbulkan hambatan untuk perkembangan bagi sebuah organisasi atau lingkungan kerja. Oleh karena itu, perlu ada upaya untuk memperbaiki hubungan interpersonal yang rusak tersebut, salah satu cara yang dapat digunakan adalah dengan pemaafan. Pemaafan merupakan salah satu elemen penting yang memberikan kontribusi dalam membangun hubungan yang harmonis atau memperbaiki hubungan yang disharmonis di tempat kerja. Sehingga secara umum ketidakmampuan untuk pemaafan pada individu-individu dalam sebuah organisasi atau di tempat kerja telah menyebabkan rendahnya tingkat performan pada semua level organisasi atau struktur di tempat kerja (Bottom, dkk., 2002; Madsen, dkk., 2009).

Selain faktor hubungan interpersonal, faktor lain yang juga mempengaruhi kesehatan mental individu di tempat kerja adalah faktor psikologis dan sifat kepribadian. Syukur merupakan salah 
satu kondisi psikologis sebagai sebuah emosi, sikap, kebajikan moral, sifat kepribadian, atau sebuah cara merespon yang dapat memberi kontribusi terhadap kesehatan mental (McCullough, Emmons, \& Tsang, 2002). Perasaan yang mendorong untuk berterima kasih dan mengapresiasi atas kesenangan yang telah diterima. Sehingga menimbulkan kondisi tenang, puas secara psikologis (Watkins, Woodward, Stone, \& Kolts, 2003)

Dengan demikian dapat pula dipahami syukur adalah kondisi di mana seseorang merasakan perasaan senang atau puas terhadap apa yang diterimanya, sehingga syukur memunculkan kondisi psikologi positif yang dapat menguatkan dan meningkatkan kesehatan mental. Seorang individu dikatakan mempunyai kesehatan mental yang baik jika ia mempunyai tingkat kesejahteraan psikologis yang tinggi dan tingkat stress yang rendah. Beberapa penelitian yang telah memperkuat pendapat tersebut adalah penelitian yang telah dilakukan oleh beberapa peneliti (Toussaint \& Friedman, 2009; Watkins, dkk., 2003; Emmons \& McCullough, 2003). Ketiga penelitian tersebut menunjukkan bahwa ada hubungan yang signifikan antara syukur dengan kesehatan mental.

Salah satu penelitian yang telah menguji pengaruh pemaafan dan syukur terhadap tinggi rendahnya kesehatan mental, telah dilakukan oleh Toussaint \& Friedman (2009) yang menemukan korelasi positif antara pemaafan dengan kesejahteraan psikologis dan berkorelasi negatif dengan tekanan emosional. Selain itu, penelitian ini juga menemukan bahwa kemampuan syukur berhubungan positif dengan kesejahtreaan psikologis dan berkorelasi negatif dengan tekanan emosional.

Dari uraian-uraian di atas maka dapat disimpulkan bahwa problem kesehatan mental di tempat kerja perlu menjadi fokus penting dan utama dalam setiap organisasi atau lembaga. Problem kesehatan mental pekerja akan dapat berdampak pada terhambatnya produktivitas pekerja, salah satu indikatornya perasaan tidak aman dan nyaman di tempat kerja, cemas, dan keengganan untuk hadir (absenteeism). Penelitian ini berusaha untuk memberikan solusi bagi problem kesehatan mental di tempat kerja, khususnya yang berkaitan hubungan interpersonal dan konflik di tempat kerja, yaitu dengan menguji kontribusi pemaafan dan syukur terhadap kesehatan mental di tempat kerja.

\section{E T O D E}

\section{Partisipan}

Partisipan penelitian adalah dosen dan karyawan Universitas Islam Negeri (UIN) Maulana Malik Ibrahim Malang sebanyak 167 orang. Ditinjau dari jenis pekerjaan partisipan penelitian untuk dosen diambil dari berbagai fakultas sebanyak 107 orang, sedangkan untuk karyawan selain diambil dari berbagai fakultas juga diambil dari rektorat dan perpustakaan yang berada di lingkungan Universitas Islam Negeri (UIN) Maulana Malik Ibrahim Malang sebanyak 60 orang. Dari aspek jenis kelamin, partisipan penelitian perempuan sebanyak $68(40.72 \%)$ orang dan partisipan laki-laki sebanyak 99 (59\%) orang. Dari aspek lamanya bekerja, sebanyak 71 orang (42.51\%) memiliki masa kerja lebih dari 10 tahun dan sebanyak 96 orang (57.49\%) kurang dari 10 tahun. Tabel 1 berikut menjelaskan karakteristik partisipan penelitian

Tabel 1. Karakteristik Partisipan Penelitian

\begin{tabular}{|c|c|c|c|c|c|}
\hline \multirow{2}{*}{ No } & \multirow{2}{*}{ Karakteristik } & \multirow{2}{*}{ Deskripsi } & \multicolumn{2}{|c|}{ Jumlah } & \multirow{2}{*}{ Jumlah } \\
\hline & & & Partisipan & $\%$ & \\
\hline \multirow[t]{2}{*}{1} & Jenis Pekerjaan & Dosen & 107 & 64.07 & \multirow[b]{2}{*}{167} \\
\hline & & Karyawan & 60 & 35.93 & \\
\hline \multirow[t]{2}{*}{2} & Jenis Kelamin & Laki-laki & 99 & 59.28 & \multirow{2}{*}{167} \\
\hline & & Perempuan & 68 & 40.72 & \\
\hline \multirow[t]{2}{*}{3} & Lama Masa Kerja & $\geq 10$ tahun & 71 & 42.51 & \multirow{2}{*}{167} \\
\hline & & $<10$ tahun & 96 & 57.49 & \\
\hline \multirow[t]{2}{*}{4} & Status Pekerjaan & PNS & 105 & 62.87 & \multirow{2}{*}{167} \\
\hline & & Non-PNS & 62 & 37.13 & \\
\hline
\end{tabular}




\section{Pengukuran}

Ada tiga jenis skala yang digunakan untuk mengukur tiga variabel dalam penelitian ini. Dua skala tentang syukur dan pemaafan tidak dilakukan pengujian reliabilitas karena merupakan skala yang diadaptasi dari skala sebelumnya yang telah memenuhi persyaratan validitas dan reliabilitas, sedangkan skala kesehatan mental dilakukan pengujian validitas dan reliabilitas karena merupakan alat ukur hasil modifikasi (mengurangi, menambahi dan merubah) aitem dari skala Mental Health Inventory.

Kesehatan mental diartikan sebagai terwujudnya keserasian antara fungsi kejiwaan dan terciptanya penyesuaian diri antara individu dengan dirinya dan lingkungannya. Data ini diperoleh melalui alat ukur modifikasi penulis terhadap alat ukur Mental Health Inventory (MHI-38) yang telah dibuat oleh Veit dan Ware (1983). Aspek yang diungkap oleh alat ukur ini adalah kondisi kesehatan mental positif (perasaan positif secara umum, kondisi emosional atau rasa cinta, dan kepuasan hidup) dan kondisi kesehatan mental negatif (kecemasan, depresi, dan hilangnya kontrol perilaku dan emosi). Alat ukur ini berupa skala likert yang jawabannya berupa pilihan dengan enam alternatif jawaban.

Selanjutnya Aziz (2015) melakukan proses modifikasi dan menguji alat ukur kesehatan mental dengan menggunakan pendekatan Rasch model pada 60 karyawan UIN Maulana Malik Ibrahim Malang. Selanjutnya dijelaskan bahwa proses modifikasi alat ukur ini dilakukan dengan menggunakan beberapa cara, diantaranya adalah; 1 ) mengurangi jumlah aitem, yang semula adalah 38 aitem tapi pada skala ini dikurangi menjadi 24 aitem yang terdiri dari 6 sub-variabel (indikator); 2) menambah jumlah aitem. Jumlah aitem pada mental health inventory (MHI) komposisi antar indikatornya tidak seimbang, ada yang banyak ada yang sedikit. Misalnya untuk indikator kepuasan hidup jumlahnya hanya 1 aitem padahal untuk indikator depresi jumlahnya ada 19 aitem karena itu pada skala ini jumlahnya diseimbangkan sehingga menjadi 4 aitem untuk masing-masing indikator; 3) Merubah redaksi aitem, yang redaksi bahasanya kurang cocok untuk konteks penelitian, redaksinya dirubah menjadi lebih kontekstual. Namun demikian, ada juga aitem yang redaksinya sesuai dengan aslinya; dan 4) mengurangi alternatif jawaban yang sebelumnya berjumlah 6 pilihan dirubah menjadi 4 alternatif pilihan yaitu hampir setiap saat, sering sekali, jarang, dan tidak pernah.

Selanjutnya, hasil pengujian alat ukur kesehatan ditemukan bahwa nilai $\alpha=.88$ artinya reliabilitas yang diperoleh alat ukur ini tinggi dan berdasarkan hasil analisis yang diperoleh dari item measure diperoleh informasi bahwa aitem yang paling mudah disetujui oleh responden adalah aitem nomor C1 (kesehatan mental aspek kecemasan 1) karena nilai logit aitem menunjukkan angka 2.20 yang merupakan aitem dengan nilai logit tertinggi sedangkan aitem yang paling susah disetujui oleh responden adalah aitem nomor $\mathrm{H} 1$ (kesehatan mental aspek kehilangan kontrol 1) karena nilai logit aitem menunjukkan angka -1.56 yang merupakan aitem dengan nilai logit terendah.

Kemampuan syukur diartikan sebagai sikap seseorang berupa menerima, mengambil manfaat, dan menilai positif sebagai tanggapan dari apa yang telah diberikan Allah atau orang baik sesuatu yang menyenangkan maupun yang tidak menyenangkan. Pengukuran kemampuan syukur yang digunakan pada penelitian ini berupa skala yang dimodifikasi penulis dari skala yang telah dikembangkan oleh McCullough, Emmons dan Tsang (2002) yang mengukur kemampuan syukur dilihat dari indikator kognitif dan emosional. Alat ukur ini terdiri dari 6 aitem yang bentuknya berupa skala Likert dengan empat alternatif jawaban yaitu sangat tepat seperti saya, seringkali seperti saya, tidak seperti saya, dan tidak seperti saya sama sekali.

Tabel 3. Blueprint Skala Kemampuan Syukur

\begin{tabular}{cccc}
\hline \multirow{2}{*}{ No } & \multirow{2}{*}{ Indikator } & \multicolumn{2}{c}{ Aitem } \\
\cline { 3 - 4 } & & Nomor & Jumlah \\
\hline 1 & Aspek kognitif & $1,2,3$ & 3 \\
2 & Aspek emosional & $4,5,6$ & 3 \\
\hline \multicolumn{3}{r}{ Jumlah } & 6 \\
\hline
\end{tabular}


Pemaafan diartikan sebagai suatu persepsi tentang adanya suatu yang bersifat transenden dalam kehidupan dan persepsi tentang keterlibatan dengan peristiwa-peristiwa transenden dalam kehidupan sehari-hari. Pengukuran pemaafan yang digunakan pada penelitian ini berupa skala Heartland Forgiveness Scale yang telah dikembangkan oleh Yamhure Thompson, Snyder dan Hoffman (2005). Bentuknya berupa skala Likert dengan tujuh alternatif jawaban. Skala ini mampu mengungkap indikator pemaafan diri sendiri, pemaafan orang lain, dan pemaafan situasi. Skala ini bentuknya berupa pernyataan tentang suatu keadaan yang terjadi atau seandainya terjadi pada seseorang. Untuk mendapatkan konsistensi jawaban partisipan, bentuk aitemnya dibuat dengan menggunakan dua jenis yaitu aitem favorable dan unfavorable. Partisipan diminta untuk menjawab dengan empat alternatif jawaban yaitu sangat tepat seperti saya, seringkali seperti saya, tidak seperti saya, dan tidak seperti saya sama sekali. Alat ukur ini terdiri dari 18 aitem, dengan sebaran:

Tabel 4. Sebaran Aitem Skala Pemaafan

\begin{tabular}{llcc}
\hline \multirow{2}{*}{ No } & \multicolumn{2}{c}{ Indikator } & \multicolumn{2}{c}{ Aitem } \\
\cline { 3 - 4 } & & $1,2,3,4,5,6$ & Jumlah \\
\hline 1. & Pemaafan pada diri sendiri & $7,8,9,10,11,12$ & 6 \\
2. & Pemaafan pada orang lain & $13,14,15,16,17,18$ & 6 \\
3. & Pemaafan pada situasi & & 6 \\
\hline & \multicolumn{2}{c}{ Jumlah } & \\
\hline
\end{tabular}

\section{Analisis Data}

Analisis data dilakukan dengan menggunakan teknik analisis regresi ganda yang bertujuan untuk mempelajari pengaruh beberapa variabel bebas (syukur dan pemaafan) terhadap variabel terikat (kesehatan mental).

\section{HASIL PENELITIAN}

Hasil uji normalitas dengan menggunakan teknik Kolmogorov-Smirnov pada variabel kesehatan mental ditemukan skor $\mathrm{z}$ sebesar .456 dengan nilai p sebesar .985 ( $\mathrm{p}>.05)$, variabel syukur ditemukan skor z sebesar 1.704 dengan nilai p sebesar .006 ( $p<.05)$, variabel pemaafan ditemukan skor z sebesar 1.191 dengan nilai p sebesar.117 ( $p>.05)$. Hasil analisis analisis selengkapnya dapat di lihat Tabel 5 berikut ini:

Tabel 5. Hasil Uji Normalitas Sebaran

\begin{tabular}{lccc}
\hline & $\begin{array}{c}\text { Kesehatan } \\
\text { Mental }\end{array}$ & Syukur & Pemaafan \\
\hline $\mathrm{N}$ & 167 & 167 & 167 \\
Kolm-Smirnov Z & .456 & 1.704 & 1.191 \\
Asy Sig.(2-tailed) & .985 & .006 & .117 \\
\hline
\end{tabular}

Hasil uji linearitas dengan menggunakan teknik analysis of variance (ANOVA) diperoleh hasil sebagai berikut.

Tabel 6. Hasil Uji Linearitas Hubungan

\begin{tabular}{lcc}
\hline \multicolumn{1}{c}{ Variabel yang diuji } & F & Nilai p \\
\hline Syukur dengan kesehatan mental & 6.973 & .010 \\
Pemaafan dengan kesehatan mental & 16.529 & .000 \\
\hline
\end{tabular}

Hasil pengujian normalitas di atas menunjukkan bahwa sebaran data pada variabel kesehatan mental dan pemaafan dinyatakan normal $(p>05)$, sedangkan variabel kemampuan syukur 
dinyatakan tidak normal $(\mathrm{p}<.05)$. Hasil pengujian linearitas di atas menunjukkan bahwa semua hubungan variabel yang diuji dinyatakan linear $(\mathrm{p}<.05)$.

Berdasarkan hasil pengujian deskriptif ditemukan bahwa variabel penelitian kesehatan mental dan syukur mempunyai rerata empiris yang lebih tinggi dibandingkan dengan rerata hipotetiknya. Artinya kondisi partisipan pada ketiga variabel tersebut berada pada kategori tinggi. Sebaliknya untuk variabel pemaafan mempunyai rerata empiris yang lebih rendah dibanding rerata hipotetisnya. Artinya kondisi partisipan pada variabel tersebut berada pada kategori rendah. Untuk melihat perbandingan rerata hipotetis dan empiris dapat di lihat pada Tabel 7 di bawah ini.

Tabel 7. Deskripsi Skor Partisipan Penelitian

\begin{tabular}{lcc}
\hline \multirow{2}{*}{ Nama Variabel } & \multicolumn{2}{c}{ Skor Rerata } \\
\cline { 2 - 3 } & Hipotetis & Empiris \\
\hline Kesehatan Mental & 60 & 136.04 \\
a. Tekanan psikologis & 30 & 36.47 \\
b. Kesejahteraan psikologis & 30 & 38.01 \\
Pemaafan & 45 & 54.65 \\
Kemampuan syukur & 15 & 20.80 \\
\hline
\end{tabular}

Hasil perbandingan rerata empiris dan hipotetis terhadap tiga variabel pada tabel di atas menunjukkan, secara keseluruhan rerata empiris kesehatan mental yang diperoleh partisipan lebih tinggi jika dibandingkan dengan rerata hipotesisnya (136.04:60) artinya tingkat kesehatan mental partisipan berada pada kategori tinggi. Sedangkan dilihat dari setiap aspek kesehatan mental menunjukkan 1) rerata empiris kesehatan mental aspek tekanan psikologis yang diperoleh partisipan lebih tinggi jika dibandingkan dengan rerata hipotesisnya (36.47:30) artinya tingkat tekanan psikologis partisipan berada pada kategori tinggi. Begitu juga rerata empiris kesehatan mental aspek kesejahteraan psikologis yang diperoleh partisipan lebih tinggi jika dibandingkan dengan rerata hiipotesis (38.01 : 30) artinya tingkat kesejahteraan psikologis partisipan berada pada kategori tinggi. Rerata empiris pemaafan yang diperoleh partisipan lebih tinggi jika dibandingkan dengan rerata hipotesisnya (54.65 : 45) artinya tingkat pemaafan partisipan berada pada kategori tinggi. Hal yang sama juga terlihat pada rerata empiris syukur yang diperoleh partisipan lebih tinggi jika dibandingkan dengan rerata hipotesisnya (20.80:15) artinya tingkat syukur partisipan juga berada pada kategori tinggi.

Hasil analisis regresi tentang pengaruh pemaafan dan syukur terhadap kesehatan mental menunjukkan nilai $\mathrm{R}=.462$ dengan koefisien determinan sebesar .213 namun setelah dilakukan penyesuaian (adjusted R squre) koefisien korelasinya berubah menjadi .204. Hal ini berarti pemaafan dan syukur mampu menjadi prediktor sebesar $20.4 \%$ bagi tinggi rendahnya kesehatan mental. Hasil tersebut menunjukkan bahwa hipotesis yang menyatakan bahwa syukur dan pemaafan berpengaruh terhadap kesehatan mental adalah diterima, semakin tinggi syukur dan pemaafan seseorang maka semakin tinggi pula tingkat kesehatan mentalnya, dan sebaliknya semakin rendah syukur dan pemaafan seseorang maka semakin rendah pula tingkat kesehatan mentalnya.

Selanjutnya, hasil analisis hubungan antara pemaafan dengan kesehatan mental menunjukkan korelasi sebesar $\beta=.279(\mathrm{p}<.05)$ dan syukur dengan kesehatan mental menunjukkan korelasi sebesar $\beta=.292(\mathrm{p}<.05)$. Ini berarti variabel syukur mempunyai pengaruh yang lebih tinggi dibandingkan dengan variabel pemaafan terhadap tinggi rendahnya kesehatan mental di tempat kerja.

\section{IS K U S I}

Hasil penelitian menunjukkan bahwa pemaafan mampu menjadi prediktor bagi tinggi rendahnya kesehatan mental pada sivitas akademika Universitas Islam Negeri Malang. Hasil tersebut memperkuat pendapat Kulcsár (2006) yang menyatakan bahwa pemaafan selalu berhubungan dengan kesehatan, baik secara fisik maupun mental. Selain itu, penelitian yang dilakukan oleh INSAN Jurnal Psikologi dan Kesehatan Mental 2017, Vol. 2(1), 33-43 
Maltby, Day, dan Barber (2004) menemukan bahwa pemaafan berkorelasi dengan aspek-aspek kesehatan mental, demikian juga dengan penelitian yang dilakukan oleh beberapa peneliti lain selalu menemukan hal yang sama.

Secara teoritis mengapa pemaafan dapat meningkatkan kesehatan mental dijelaskan oleh Enright (2001) melalaui empat tahapan proses pemaafan yaitu: pertama, tahap mengungkap atau membuka. merupakan tahap fundamental dalam proses pemaafan di mana seseorang telah mencapai pemahaman apakah dan bagaimana ketidakadilan mengakibatkan cedera atau luka, namun dia telah mampu mengkompromikan dalam kehidupannya. kemudian menawarkan pengampunan kepada seseorang yang telah melukai. Kedua, tahap memutuskan, yaitu seseorang telah mencapai pemahaman yang benar tentang pemaafan yang sesungguhnya dan membuat keputusan untuk berkomitmen pemaafan berdasarkan pemahamannya tersebut.

Ketiga, tahap bertindak atau bekerja. Pada tahap ini seseorang telah mencapai sebuah pemahaman kognitif terhadap orang yang telah melukai dirinya dan memulai memandangnya dalam perspektif baru yang lebih holistik dan menghasilkan perubahan positif dalam memandang hubungan dengan orang yang bersalah, dirinya, dan lingkungannya. Tindakan nyata pemaafan yang dimaksud dalam tahap ini adalah memulai memahami orang yang bersalah dalam perspektif baru yang lebih akurat, memahami situasi terjadinya masalah, dan memandang bahwa orang yang bersalah sebagai manusia dan bukanlah penjelmaan dari sesuatu yang jahat. Tindakan lainnya dalam tahap ini meliputi bertindak empati secara realistis dan mengasihi pelaku, berani dan tegas meskipun berdampak rasa sakit yang disebabkan oleh pelanggaran. Dan akhirnya memberikan pelaku "hadiah moral" pengampunan. Keempat, Tahap pendalaman yaitu, seseorang menemukan peningkatan makna dalam penderitaan, merasa lebih terhubung dengan orang lain, dan pengaruh pengalaman negatif menurun, pada saat yang bersamaan memperbaharui tujuan hidup (Enright, 2001).

Dari empat tahapan yang dikemukakan oleh Enright (2001) menunjukkan bahwa pemaafan adalah sebuah proses di mana orang dapat menemukan dirinya terlepas dari "penjara emosional" (tidak pemaafan, kepahitan, kebencian dan kemarahan). Karena kemampuan seseorang untuk pemaafan secara tulus dan mendalam, orang dapat menemukan makna baru dalam penderitaan dan tujuan baru dalam hidupnya. maka dapat dipahami bahwa ada proses psikologis yang mampu menjadi katarsis pada aspek yang menjadi tekanan psikologis pada seseorang, sekaligus ada proses yang memungkinkan pada seseorang untuk mengembangkan aspek kesejahteraan psikologisnya. Kondisi tersebut merupakan indikator dari individu yang sehat secara mental.

Selanjutnya, hasil penelitian yang menguji variabel syukur menunjukkan bahwa secara positif syukur juga mempengaruhi tinggi rendahnya kesehatan mental daitempat kerja. Hasil penelitian ini konsisten dengan penelitian sebelumnya yang menyatakan bahwa syukur dapat menjadi faktor prediktor bagi kesehatan mental pekerja (Lanham, Rye, Rimsky, \& Weill, 2012; Park, Peterson, \& Seligman, 2004).

Ada beberapa alasan mengapa syukur dapat meningkatkan kesehatan mental di tempat kerja, yaitu syukur dapat mengurangi perasaan bosan yang biasanya menjadi pemicu stres bagi para pekerja serta meningkatkan kepuasan bekerja (Lanham, dkk., 2012), mendorong perilaku prososial di tempat kerja (Bartlett \& DeSteno, 2006; Bono, Emmons, \& McCullough, 2004; McCullough, Tsang, \& Emmons, 2004), memotivasi orang untuk bekerja sama dan bertanggung jawab secara sosial (Andersson, Giacalone, \& Jurkiewicz, 2007) dan memberikan persepsi positif di tempat kerja (Watkins, Grimm, \& Kolts, 2004). Secara moral, syukur dapat menstimulasi orang untuk berprilaku moral, yaitu perilaku yang memotivasi untuk menghargai dan memahami orang lain seperti empati dan simpati (McCullough, Kilpatrick, Emmons, \& Larson, 2001). Syukur dapat memlihara hubungan interpersonal yang harmonis (Algoe, Haidt, \& Gable, 2008). Perilaku-perilaku tersebut akan menciptakan suasana yang nyaman bagi hubungan interpersonal dan menimbulkan emosi positif yang merupakan bagian dari konstruk syukur.

Hasil pengujian secara bersama-sama pengaruh pemaafan dan syukur terhadap kesehatan mental menunjukkan bahwa kedua variabel tersebut menentukan tingkat kekuatan kesehatan mental. Hasil 
penelitian ini konsisten dengan penelitian yang telah dilakukan oleh Toussaint \& Friedman, (2009) yang menemukan adanya pengaruh pemaafan dan syukur terhadap kesejahteraan psikologis. Artinya syukur dan pemaafan keduanya berpengaruh secara signifikan terhadap kesejahteraan psikologis. Konsep kesejahteraan psikologis ini terkadang diartikan sama dengan istilah kesehatan mental karena ada beberapa indikator yang sama.

Bila dicermati, dari hasil analisis diketahui bahwa dibandingkan pemaafan, kontribusi syukur terhadap kesehatan mental di tempat kerja lebih besar skornya. Kondisi tersebut dapat dijelaskan dengan memahami beberapa aspek dari karakteristik pemaafan dan syukur Dari aspek sumber atau pemicu, pemaafan muncul karena ada orang (transgetor) atau peristiwa yang melukai atau menyakiti sehingga menimbulkan emosi negatif (Madsen, dkk., 2009; Worthington \& Scherer, 2004; Kulcsár, 2006). Sedangkan syukur muncul karena adanya peristiwa atau pemberi baik dari Tuhan atau orang (benefactor) yang menimbulkan emosi positif yaitu perasaan kagum, kesenangan, dan harapan (Bono , dkk., 2004, Emmons \& Mishra, 2011).

Pada aspek proses, pemaafan merupakan proses seseorang mengubah dari kondisi tidak pemaafan (unforgiveness) yang mengandung emosi negatif (sakit hati, marah, jengkel, tertekan) ke kondisi pemaafan yang mengandung sejumlah emosi positif (cinta, kasih sayang, empati, simpati) (Worthington \& Scherer, 2004). Hal tersebut berbeda dengan syukur yang dimulai dari pengalaman kekaguman yaitu tahap seseorang menerima dan menyetujui perbuatan dari pemberi kemudian menimbulkan perasaaan senang karena menjadi pribadi yang menguntungkan atau bermanfaat (Algoe, Gable, \& Maisel, 2010).

Dari aspek dampak yang ditimbulkan, pemaafan dapat menghilangkan emosi negatif namun ingatan menjadi orang yang dilukai masih tersimpan dalam memori, sehingga sewaktu-waktu dapat beresiko terhadap kesehatan mental. Pemaafan juga dapat memilihara hubungan interpersonal yang baik (Satici, Uysal, \& Akin, 2014). Sedangkan syukur dalam konteks di tempat kerja memiliki dampak yang positif baik secara individual maupun organisasional ((Waters, 2012), meningkatkan perilaku prososial (Bartlett \& DeSteno, 2006) Syukur dapat memlihara hubungan interpersonal yang harmonis (Algoe, Haidt, \& Gable, 2008).

Dari penjelasan di atas dapat dipahami, mengapa skor syukur lebih tinggi mempengaruhi kesehatan mental dibandingkan pemaafan. Syukur secara langsung ditimbulkan oleh emosi positif, yaitu rasa kagum dan menyenangkan sehingga lebih mudah menciptakan kondisi sejahterah secara psikologi. Selain itu, dampak syukur mendorong orang untuk berprilaku sesuai dengan norma-norma sosial yang menyebabkan dia lebih mudah diterima secara sosial. Kondisi tersebut memberikan rasa sejahtera secara sosial sebagai salah satu konstruk kesehatan mental selain kesejahteraan psikologi.

Berbeda dengan pemaafan yang sumber pemicunya adalah kondisi atau situasi yang tidak menyenangkan sehingga menimbulkan emosi negatif. Proses dari tidak pemaafan (unforgiveness) sampai memutuskan untuk pemaafan (forgiveness) yang dialami oleh penderita atau korban yang disakiti lebih kompleks dan terkadang membutuhkan waktu untuk mencapai kesejahteraan secara psikologis. Meskipun pemaafan berdampak terhadap penciptaan hubungan interpersonal yang baik, namun demikian keputusan pemaafan bukan berarti seseorang menghilangkan ingatan atau memori dirinya sebagai korban, sehingga ada kecenderungan orang menarik diri dari konteks sosial. Dengan kata lain pemaafan merupakan kondisi yang sangat kompleks dibandingkan syukur dalaam memberi kontribusi terhadap kesehatan mental.

\section{S I M P U L A N}

Dari uraian diatas dapat disimpulkan bahwa bersyukur dan memaafkan mempunyai peran yang sangat penting dalam mengembangkan kesehatan mental. Bersyukur mempunyai peran yang lebih besar dalam mengembangkan kesehatan mental di tempat kerja dibandingkan dengan pemaafan. Hal itu berarti bahwa untuk mengembangkan kesehatan mental di tempat kerja maka yang harus dilakukan adalah dengan mulai mengembangkan kemampuan bersyukur terhadap semua karunia 
yang di terima, setelah itu berusahalah untuk mampu memaafkan terhadap semua kesalahan baik diri sendiri, orang lain dan lingkungan sekitar.

Dengan adanya berbagai keterbatasan dalam penelitian ini, maka ada beberapa saran yang disampaikan pada peneliti lebih lanjut dalam upaya untuk lebih memahami dan upaya preventif dalam mengembangkan kesehatan mental di tempat kerja. Perlu dicari desain penelitian yang lebih memadai dalam upaya pemahaman terhadap kesehatan mental. Salah satu upaya yang dapat dilakukan adalah dengan memperbanyak variabel baik bebas maupun mediator yang dapat berfungsi untuk menjelaskan faktor yang berpengaruh terhadap kesehatan mental. Selain itu, perlu dilakukan pengujian validitas dan reliabilitas terhadap instrumen penelitian, khususnya pada variabel pemaafan dan syukur. Karena kedua variabel tersebut tidak dilakukan pengujian validitas dan reliabilitasnya.

Penelitian ini menggunakan metode kuantitatif, sehingga memiliki keterbatasan dalam penggalian dan penyampaian data. Oleh karena itu, perlu dipertimbangkan untuk meneliti tema ini dengan pendekatan kualitatif (baik melalui observasi, wawancara, maupun FGD) atau menggunakan pendekatan kuantitatif dengan pendekatan eksperimental sehingga mampu menguji hubungan kausalitas yang lebih memadai serta ditemukan model pelatihan yang mampu mengembangkan kesehatan mentaldi tempat kerja.

\section{PUSTAKA ACUAN}

Algoe, S. B., Gable, S. L., \& Maisel, N. C. (2010). It's the little things: Everyday gratitude as a booster shot for romantic relationships. Personal relationships, 17(2), 217-233.

Algoe, S. B., Haidt, J., \& Gable, S. L. (2008). Beyond reciprocity: gratitude and relationships in everyday life. Emotion, 8(3), 425.

Andersson, L. M., Giacalone, R. A., \& Jurkiewicz, C. L. (2007). On the relationship of hope and gratitude to corporate social responsibility. Journal of Business Ethics, 70(4), 401-409.

Aziz, R., (2015), Aplikasi model Rasch dalam pengujian alat ukur kesehatan mental di tempat kerja. Psikoislamika, 12(2). 1-16.

Bartlett, M. Y., \& DeSteno, D. (2006). Gratitude and prosocial behavior: Helping when it costs you. Psychological Science, 17(4), 319-325.

Bono, G., Emmons, R. A., \& McCullough, M. E. (2004). Gratitude in practice and the practice of gratitude. Positive Psychology in Practice, 464-481.

Bottom, W. P., Gibson, K., Daniels, S. E., \& Murnighan, J. K. (2002). When talk is not cheap: Substantive penance and expressions of intent in rebuilding cooperation. Organization Science, 13(5), 497513.

Cooper, C. L., \& Cartwright, S. (1994). Healthy mind; healthy organization-A proactive approach to occupational stress. Human Relations, 47(4), 455-471.

Danna, K., \& Griffin, R. W. (1999). Health and well-being in the workplace: A review and synthesis of the literature. Journal of Management, 25(3), 357-384.

Emmons, R. A., \& McCullough, M. E. (2003). Counting blessings versus burdens: an experimental investigation of gratitude and subjective well-being in daily life. Journal of Personality and Social Psychology, 84(2), 377.

Emmons, R. A., \& Mishra, A. (2011). Why gratitude enhances well-being: What we know, what we need to know. Designing Positive Psychology: Taking Stock and Moving Forward, 248-262. 
Enright, R. D. (2001). Forgiveness is a choice: A step-by-step process for resolving anger and restoring hope. American Psychological Association. Diunduh dari http://psycnet.apa.org/psycinfo/2001$\underline{01081-000}$

Harvey, S.B., Joyce, S., Tan, L., Johnson, A., Nguyen, H., Modini, M., \& Groth, M. (2014). Developing a mentally healthy workplace: A review of the literature. A report for the National Mental Health Commission and the Mentally Healthy Workplace Alliance. Sydney: School of Psychiatry, University of New South Wales; Black Dog Institute \& Australian School of Business, University of New South Wales.

Koopman, C., Pelletier, K. R., Murray, J. F., Sharda, C. E., Berger, M. L., Turpin, R. S., ... \& Bendel, T. (2002). Stanford presenteeism scale: health status and employee productivity. Journal of Occupational and Environmental Medicine, 44(1), 14-20.

Kulcsár, A. (2006). Forgiveness and mental health. Studia Universitatis Babes-Bolyai-Theologia Catholica Latina, (1), 93-102.

Lanham, M., Rye, M., Rimsky, L., \& Weill, S. (2012). How gratitude relates to burnout and job satisfaction in mental health professionals. Journal of Mental Health Counseling, 34(4), 341-354.

Madsen, S. R., Gygi, J., Hammond, S. C., \& Plowman, S. F. (2009). Forgiveness as a workplace intervention: The literature and a proposed framework. Journal of Behavioral and Applied Management, 10(2), 246.

Maltby, J., Day, L., \& Barber, L. (2004). Forgiveness and mental health variables: Interpreting the relationship using an adaptational-continuum model of personality and coping. Personality and Individual Differences, 37(8), 1629-1641.

Marchand, A., Durand, P., Haines III, V., \& Harvey, S. (2015). The multilevel determinants of workers' mental health: results from the SALVEO study. Social Psychiatry and Psychiatric Epidemiology, 50(3), 445-459.

McCullough, M. E., Emmons, R. A., \& Tsang, J. A. (2002). The grateful disposition: a conceptual and empirical topography. Journal of Personality and Social Psychology, 82(1), 112.

McCullough, M. E., Kilpatrick, S. D., Emmons, R. A., \& Larson, D. B. (2001). Is gratitude a moral affect? Psychological Bulletin, 127(2), 249.

McCullough, M. E., Tsang, J. A., \& Emmons, R. A. (2004). Gratitude in intermediate affective terrain: links of grateful moods to individual differences and daily emotional experience. Journal of Personality and Social Psychology, 86(2), 295.

Park, N., Peterson, C., \& Seligman, M. E. (2004). Strengths of character and well-being. Journal of social and Clinical Psychology, 23(5), 603-619.

Rees, C. S., Breen, L. J., Cusack, L., \& Hegney, D. (2015). Understanding individual resilience in the workplace: the international collaboration of workforce resilience model.Frontiers in Psychology, 6, 73.

Satici, S. A., Uysal, R., \& Akin, A. (2014). Forgiveness and vengeance: The mediating role of gratitude. Psychological Reports, 114(1), 157-168.

Toussaint, L., \& Friedman, P. (2009). Forgiveness, gratitude, and well-being: The mediating role of affect and beliefs. Journal of Happiness Studies, 10(6), 635.

Veit, C. T., \& Ware, J. E. (1983). The structure of psychological distress and well-being in general populations. Journal of consulting and clinical psychology, 51(5), 730.

INSAN Jurnal Psikologi dan Kesehatan Mental

2017, Vol. 2(1), 33-43

doi: 10.20473/jpkm.v2i12017.33-43 
Waters, L. (2012). Predicting job satisfaction: Contributions of individual gratitude and institutionalized gratitude. Psychology, 3(12A special issue), 1174.

Watkins, P. C., Grimm, D. L., \& Kolts, R. (2004). Counting your blessings: Positive memories among grateful persons. Current Psychology, 23(1), 52-67.

Watkins, P. C., Woodward, K., Stone, T., \& Kolts, R. L. (2003). Gratitude and happiness: Development of a measure of gratitude, and relationships with subjective well-being. Social Behavior and Personality: An International Journal, 31(5), 431-451.

Worthington, E. L., \& Scherer, M. (2004). Forgiveness is an emotion-focused coping strategy that can reduce health risks and promote health resilience: Theory, review, and hypotheses. Psychology \& Health, 19(3), 385-405.

Yamhure Thompson, L., Snyder, C. R., \& Hoffman, L. (2005). Heartland forgiveness scale. Diunduh dari http://digitalcommons.unl.edu/psychfacpub/452/ 